\title{
Mutual relationships among body condition score, live weight, and back tissue development in meat sheep
}

\author{
Martin Ptáček, Jaromír Ducháček, Luděk Stádník, Jan Beran \\ Czech University of Life Sciences Prague, Faculty of Agrobiology, Food and Natural Resources, \\ Department of Animal Husbandry, Czech Republic \\ Received September 17, 2013 \\ Accepted July 23, 2014
}

\begin{abstract}
Body tissue development and proportion affect predisposition to optimum functioning of production attributes, health, and fertility of sheep. Therefore, the objective of this study was to determine relationships among indicators of mature ewes' nutritional status documented by the body condition score and live weight using ultrasonic evaluation of backfat thickness and depth of musculus longissimus lumborum et thoracis. The monitoring was carried out in Suffolk sheep $(\mathrm{n}=942)$ for a period of 2 years. A significant increase $(P<0.05$ to $P<0.01)$ of all the evaluated indicators was detected corresponding to an increase of the body condition score from 1 to 5 points. The differences in ewes' live weights depending on particular condition scores reached up to $31.04 \mathrm{~kg}$ with the lowest value $(58.71 \mathrm{~kg})$ in 1 point and the highest $(89.75 \mathrm{~kg})$ in 5 points. The variability of backfat thickness and muscle depth depending on individual condition scores was up to $352.08 \%(11.02 \mathrm{~mm})$ in backfat thickness and up to $50.10 \%(12.83 \mathrm{~mm})$ in muscle depth $(P<0.05$ to 0.01$)$ compared to the lowest condition score of 1 point. Strong positive linear relationships were also detected between the live weight and back tissues development in ewes $(P<0.001)$. This study innovatively determinates mutual relationships among growth indicators and body tissue development performed on intensive meat-purpose sheep in vivo. Results of the present study could serve in flock management as a tool for evaluation of the current nutritional status as well as a basic ground for further research focused on development of sheep fattiness and carcass traits evaluation.
\end{abstract}

Suffolk, backfat thickness, musculus longissimus lumborum et thoracis depth

The total milk as well as meat efficiency of sheep is dependent on an adequate forage intake, its energy and microelement supply as well as microorganism activity and rumen function (Żarczyńska et al. 2012). The animal's growth ensured by nutrients of the feed ration is manifested by body development, including morphological and anatomical formation of the body, and changes in body tissue proportions or microstructure (Młynek et al. 2012). These traits determinate final commercial profitability; therefore, the animals are selected for these mentioned indicators. The basic indicators of growth and body development are the body condition score (BCS), live weight (LW), backfat thickness (BT), and the depth of musculus longissimus lumborum et thoracis (MLLT). These indicators influence $(P<0.05$ to 0.01 ) reproduction and production performance of sheep (Kenyon et al. 2004; Ptáč ek et al. 2014). Relationship between LW and BCS, or rather, relationships among BCS, LW and body tissues indicators have been previously published by Sanson et al. (1993) or Caldeira and Portugal (2007). They performed their observation on local or rustic breeds of sheep or sheep carcasses. This study differs from others in detailed analysis of mutual relationships among selected indicators of growth and body development in live animals, concurrently showing their development. Despite the importance of these relationships, no current study has manifested these results on intensively bred meat sheep breeds in vivo. Therefore, the aim of our study was to determine relationships among selected indicators of growth and body development in meat sheep, detecting the proportion of individual back tissues and their mutual relationships.

Address for correspondence:

Ing. Martin Ptáček

Department of Animal Husbandry

Faculty of Agrobiology, Food and Natural Resources

Czech University of Life Sciences Prague

Kamýcká 129, 16521 Prague 6 - Suchdol, Czech Republic

Phone: + 420224383070

E-mail: ptacekm@af.czu.cz

http://actavet.vfu.cz/ 


\section{Materials and Methods}

The monitoring was performed in Suffolk sheep (SF; $n=942)$ during 2 subsequent years. Observed sheep were bred under similar conditions (at the altitude of 290 to $350 \mathrm{~m}$ above the sea level, with the average annual rainfall of 650 to $800 \mathrm{~mm}$ per year and annual temperature of 7.5 to $11^{\circ} \mathrm{C}$ ) on three different farms located in the Central Bohemia region. The feed ration during the grazing season consisted of grassland pasture only. Flushing as a tool of nutritional stimulation of sheep ovarian activity was not applied before the beginning of the mating season. The sheep had access to mineral lick and drinking water ad libitum during the whole time. In the winter period, the ewes' feed ration consisted of haylage ( $5 \mathrm{~kg}$ per head per day) and hay (ad libitum).

Evaluated traits

The body condition score (BCS), live weight (LW), backfat thickness (BT), and musculus longissimus lumborum et thoracis depth (MLLT) of ewes at mating (day before the introduction of the ram) and at weaning (on the day of separation of lambs from their mothers) were assessed. The BCS evaluation was determined by only one evaluator on a 5 point scale (BCS $1=$ emaciated, BCS $2=$ thin, BCS $3=$ average, BCS $4=$ fat, BCS 5 $=$ obese) with the accuracy of 0.5 point (Russel et al. 1969). The ewe's LW (kg; $\pm 100 \mathrm{~g}$ ) was obtained using tensometric scale VHD (My Weigh; Erkelenz, Germany) designated for the weighting of small ruminants. The assessing of BT and MLLT was performed in the area of last thoracis vertebra (both in $\mathrm{mm}$ ) using the ultrasound Aloka 500 and $5 \mathrm{MHz}$ linear probe (Hitachi Aloka Medical, Ltd.; Tokyo, Japan) in accordance with methodology stated by Milerski (2007) and Stádník et al. (2009). The flock, year and period of observation as well as age of dams were also recorded and evaluated.

Statistical evaluation

The statistical analysis of indicators of the development of the ewes' nutritional status was performed by SAS 9.3 (SAS/STAT ${ }^{\circledR}$ 9.3., 2011). The GLM procedure was used for determination of the effect of individual BCSs on LW, BT, and MLLT. The effects were selected by the REG procedure, STEPWISE method. The model equation contained the combined effect of flock, year and period of observation, age of mothers (from 1 to 6 years), and BCS (from 1 to 5 points). The Kenward and Roger (1997) method was used for degrees of freedom assessing. The Tukey-Kramer method was applied for comparison and evaluation of significant differences between least square means. In addition, mutual proportions among LW and back tissue development (BT and MLLT) were expressed from LSM results, and the REG procedure was used for the determination of these relationships in detail. Significance levels of $P<0.05, P<0.01$, and $P<0.001$ were used to evaluate the differences between groups.

\section{Results}

Coefficients of determination of observed indicators were in the range from $\mathrm{r}^{2}=0.523$ $(P<0.001)$ to $\mathrm{r}^{2}=0.739(P<0.001)$. The effect of all observed factors on the evaluated indicators was also significant $(P<0.001)$.

The differences in LSMs for the ewes' live weight (LW), backfat thickness (BT), and

Table 1. Effect of body condition score (BCS) on the live weight (LW), backfat thickness (BT), and musculus longissimus lumborum et thoracis depth (MLLT) of meat ewes.

\begin{tabular}{llll}
\hline BCS (point) & \multicolumn{1}{c}{$\begin{array}{c}\text { LW }(\mathrm{kg}) \\
\mathrm{LSM} \pm \mathrm{SE}\end{array}$} & $\begin{array}{c}\mathrm{BT}(\mathrm{mm}) \\
\mathrm{LSM} \pm \mathrm{SE}\end{array}$ & $\begin{array}{c}\text { MLLT (mm) } \\
\text { LSM } \pm \text { SE }\end{array}$ \\
\hline $1.0(\mathrm{n}=8)$ & $58.71 \pm 3.184^{\mathrm{A}}$ & $3.13 \pm 0.600^{\mathrm{A}}$ & $25.61 \pm 1.068^{\mathrm{A}}$ \\
$1.5(\mathrm{n}=5)$ & $60.97 \pm 4.037^{\mathrm{C}}$ & $3.64 \pm 0.760^{\mathrm{C} . \mathrm{a}}$ & $28.41 \pm 1.354^{\mathrm{C}}$ \\
$2.0(\mathrm{n}=35)$ & $64.56 \pm 1.549^{\mathrm{E}}$ & $4.45 \pm 0.292^{\mathrm{E}}$ & $28.06 \pm 0.520^{\mathrm{E}}$ \\
$2.5(\mathrm{n}=97)$ & $66.93 \pm 0.952^{\mathrm{G}}$ & $5.37 \pm 0.179^{\mathrm{B}, \mathrm{F}, \mathrm{G}}$ & $30.77 \pm 0.319^{\mathrm{B}, \mathrm{G}}$ \\
$3.0(\mathrm{n}=235)$ & $72.22 \pm 0.631^{\mathrm{B}, \mathrm{F}, \mathrm{H}, \mathrm{I}}$ & $7.03 \pm 0.119^{\mathrm{B}, \mathrm{F}, \mathrm{H}, \mathrm{I}, \mathrm{b}}$ & $32.78 \pm 0.212^{\mathrm{B}, \mathrm{D}, \mathrm{F}, \mathrm{H}, \mathrm{I}}$ \\
$3.5(\mathrm{n}=221)$ & $76.54 \pm 0.648^{\mathrm{B}, \mathrm{D}, \mathrm{F}, \mathrm{H}, \mathrm{J}, \mathrm{K}}$ & $8.73 \pm 0.122^{\mathrm{B}, \mathrm{D}, \mathrm{F}, \mathrm{H}, \mathrm{J}, \mathrm{K}}$ & $35.19 \pm 0.217^{\mathrm{B}, \mathrm{D}, \mathrm{F}, \mathrm{H}, \mathrm{J}, \mathrm{K}}$ \\
$4.0(\mathrm{n}=166)$ & $80.21 \pm 0.735^{\mathrm{B}, \mathrm{D}, \mathrm{F}, \mathrm{H}, \mathrm{L}, \mathrm{L}, \mathrm{M}}$ & $10.64 \pm 0.138^{\mathrm{B}, \mathrm{D}, \mathrm{F}, \mathrm{H}, \mathrm{J}, \mathrm{L}, \mathrm{M}}$ & $36.64 \pm 0.247^{\mathrm{B}, \mathrm{D}, \mathrm{F}, \mathrm{H}, \mathrm{J}, \mathrm{L}, \mathrm{M}}$ \\
$4.5(\mathrm{n}=120)$ & $82.57 \pm 0.856^{\mathrm{B}, \mathrm{D}, \mathrm{F}, \mathrm{H}, \mathrm{J}, \mathrm{L}, \mathrm{O}}$ & $11.83 \pm 0.161^{\mathrm{B}, \mathrm{D}, \mathrm{F}, \mathrm{H}, \mathrm{J}, \mathrm{L}}$ & $36.94 \pm 0.287^{\mathrm{B}, \mathrm{D}, \mathrm{F}, \mathrm{H}, \mathrm{J}, \mathrm{L}, \mathrm{N}, \mathrm{N}, \mathrm{O}}$ \\
$5.0(\mathrm{n}=55)$ & $89.75 \pm 1.234^{\mathrm{B}, \mathrm{D}, \mathrm{F}, \mathrm{H}, \mathrm{J}, \mathrm{L}, \mathrm{N}, \mathrm{P}}$ & $14.15 \pm 0.232^{\mathrm{B}, \mathrm{D}, \mathrm{F}, \mathrm{H}, \mathrm{J}, \mathrm{L}, \mathrm{N}}$ & $38.44 \pm 0.414^{\mathrm{B}, \mathrm{D}, \mathrm{F}, \mathrm{H}, \mathrm{J}, \mathrm{L}, \mathrm{L}, \mathrm{N}, \mathrm{P}}$ \\
\hline
\end{tabular}

Body condition score - BCS; backfat thickness - BT; musculus longissimus lumborum et thoracis depth - MLLT; LW - ewe live weight; LSM - least square means; SE - standard error of LSM; different superscript letters mean a significant difference within a column: $\mathrm{a}-\mathrm{b}=P<0.05$; A-B, C-D, E-F, G-H, I-J, K-L, M-N, O-P $=P<0.01$. 


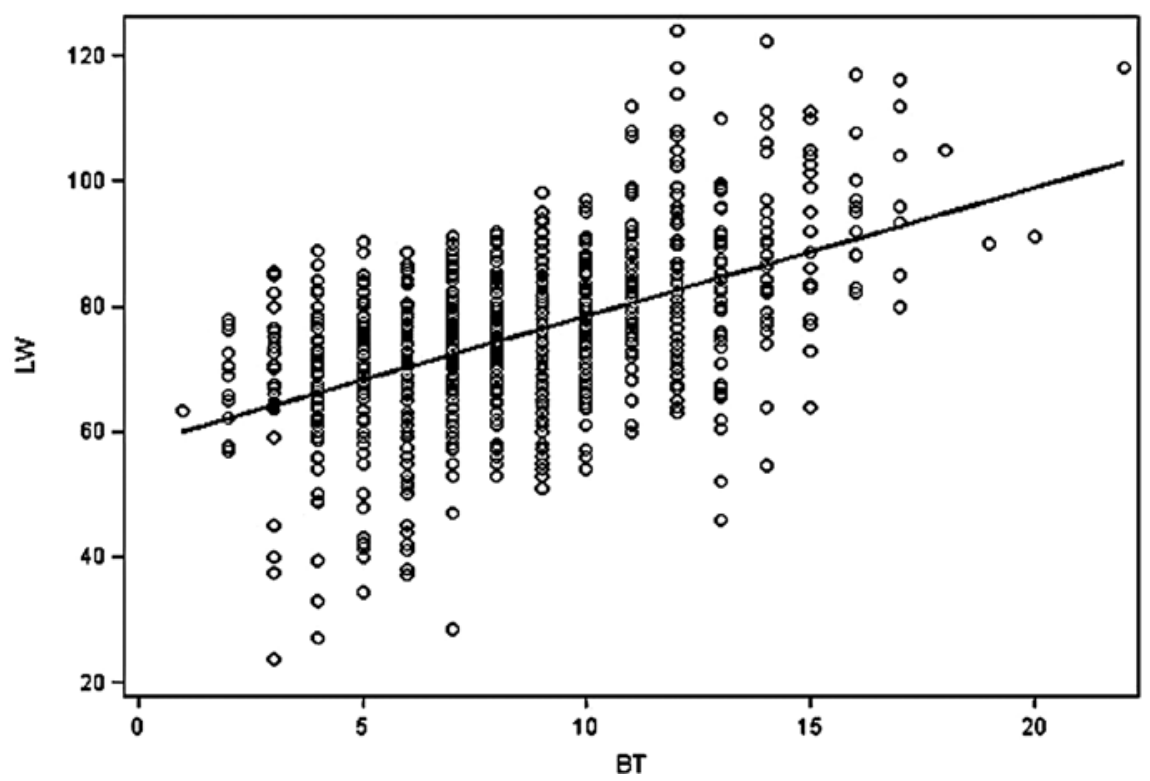

Fig. 1. Relationship between ewes' live weight in $\mathrm{kg}$ and backfat thickness in $\mathrm{mm}\left(\mathrm{r}^{2}=0.260 ; \mathrm{y}=58.355+2.004\right.$ BT; $P<0.001)$

LW - ewe live weight; BT - backfat thickness

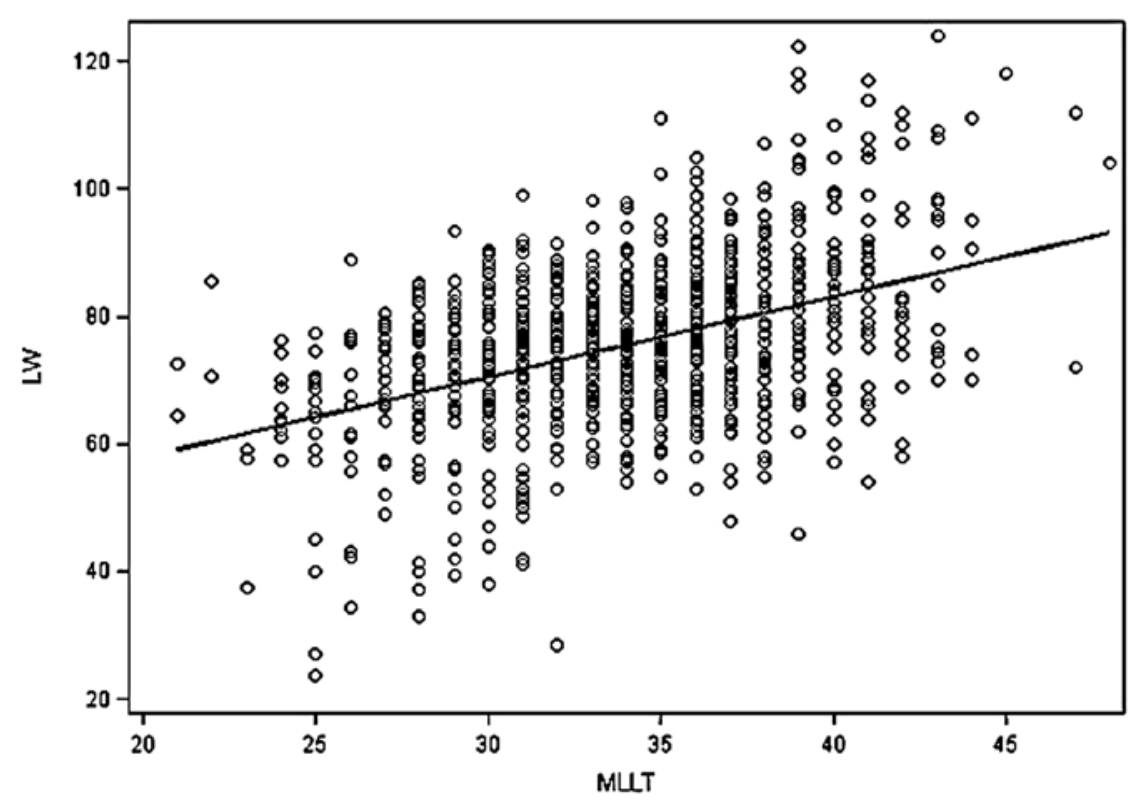

Fig. 2. Relationship between ewe live weight in $\mathrm{kg}$ and musculus longissimus lumborum et thoracis depth in $\mathrm{mm}$ $\left(\mathrm{r}^{2}=0.173 ; \mathrm{y}=34.811+1.199\right.$ MLLT; $\left.P<0.001\right)$

LW - ewe live weight; MLLT - musculus longissimus lumborum et thoracis depth 


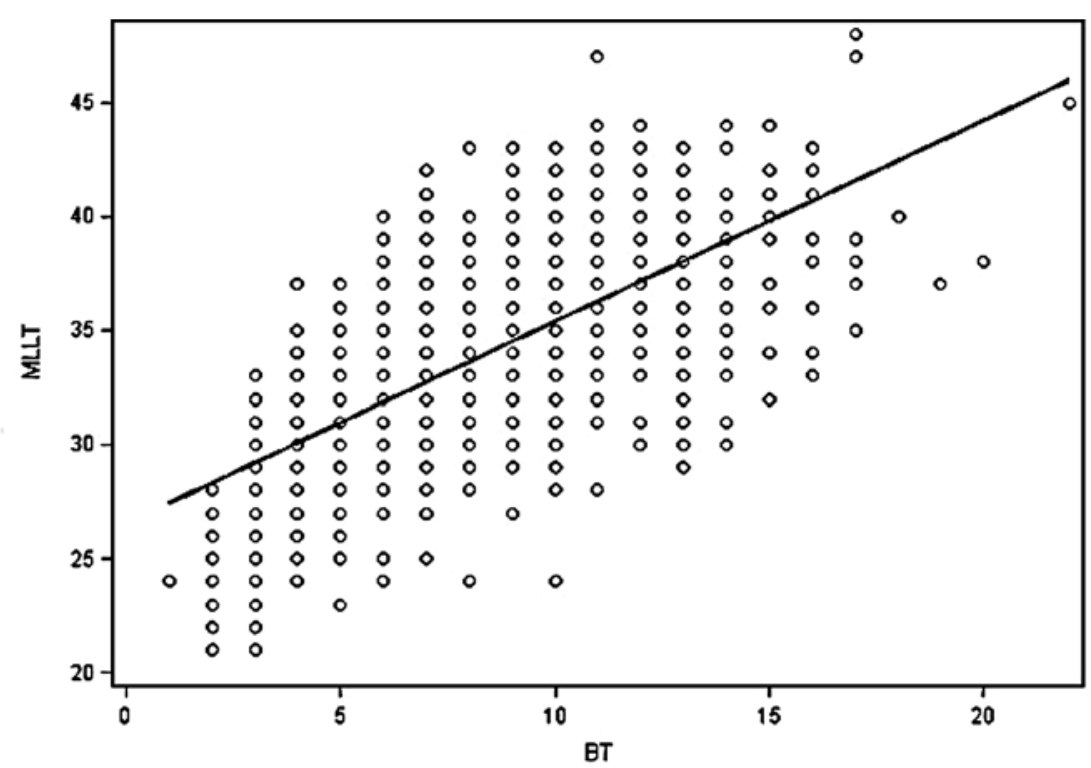

Fig. 3. Relationship between musculus longissimus lumborum et thoracis depth in mm and backfat thickness in $\mathrm{mm}\left(\mathrm{r}^{2}=0.396 ; \mathrm{y}=26.808+0.856 \mathrm{BT} ; P<0.001\right)$

MLLT - musculus longissimus lumborum et thoracis depth; BT - backfat thickness

musculus longissimus lumborum et thoracis depth (MLLT) for individual BCS points are presented in Table 1. The significant increase $(P<0.05$ to 0.01$)$ of all the evaluated indicators was detected corresponding with the BCS increase from 1 to 5 points, except for MLLT in relation to BCS 2. The LW differences with respect to particular BCS ranged up to $31.04 \mathrm{~kg}$ with the lowest value $(58.71 \mathrm{~kg})$ in BCS 1 and the highest $(89.75 \mathrm{~kg})$ in BCS 5 . The variability of BT and MLLT significantly $(P<0.05$ to 0.01$)$ depended on individual BCS, and was up to $352.08 \%$ (11.02 $\mathrm{mm}$ ) in BT and up to $50.10 \%$ (12.83 mm) in MLLT compared to the lowest BCS 1. Detailed interpretation of LW and body tissues proportions showed that the LW/BT ratio declined from 18.76 in emaciated ewes (BCS 1) to 6.34 in obese ewes (BCS 5). However, the LW/MLLT ratio presented lower values of variability, from 2.15 in emaciated ewes to 2.30 in obese ewes. Finally, the BT/MLLT rate declined linearly depending on individual BCS units from 8.18 in BCS 1 to 2.72 in BCS 5 .

Strong positive linear relationships among all the evaluated indicators of growth and back tissue development were detected $(P<0.001)$ as presented in Figs $1-3$. The higher the LW of ewes, the higher BT and MLLT were determined, and vice versa. The $1 \mathrm{~mm}$ BT or MLLT increase corresponded with $2.004 \mathrm{~kg}\left(\mathrm{r}^{2}=0.261\right)$ or $1.199 \mathrm{~kg}\left(\mathrm{r}^{2}=0.173\right)$ increase of LW. Similarly close relationship $\left(\mathrm{r}^{2}=0.396 ; P<0.001\right)$ was detected between the ewes' BT and MLLT development, when a $1 \mathrm{~mm}$ increase in BT was associated with $0.856 \mathrm{~mm}$ increase of MLLT.

\section{Discussion}

The mutual relationship between the ewes' body condition score (BCS) and their live weight (LW) has been previously published by Caldeira and Portugal (2007). According to their results there was an increase of LW with higher BCS in Serra da Estrela ewes. The LW difference between the lowest and highest BCS (1 and 4) was 
$27.99 \mathrm{~kg}$. Our results in Suffolk sheep were $3.05 \mathrm{~kg}$ higher but on the BCS scale of 1 to 5 . According to their study, 1 BCS point was equal to $9.33 \mathrm{~kg}$ of LW. However, in our study, the one BCS point increase was associated with $7.76 \mathrm{~kg}$ increase of LW. These results corresponded closer to Sezenler et al. (2011) who noted that 1 point of BCS was equivalent to 6.96 to $7.07 \mathrm{~kg}$ increase of LW performed on Kivircik, Sakiz and Gokceada sheep. According to studies of Sanson et al. (1993) and Kenyon et al. (2004), an increase of 1 BCS unit was accompanied by $+4.57 \mathrm{~kg}$ or $+7.32 \mathrm{~kg}$ of LW performed on Western-range and Romney ewes, respectively. Similar results were observed in Suffolk sheep evaluated in our study. Vatankhah et al. (2012) also pointed out that increasing the BCS by one point at mating was equal to a $\mathrm{LW}$ increase of $5.3 \%$ in origin Iranian breed of Lori-Bakhtiari sheep. In our study the differences in LW among particular BCS units ranged from 5.85 to $9.54 \mathrm{~kg}$ which represented 9.96-12.02\% related to the lightest sheep $(\mathrm{LW}=58.71 \mathrm{~kg})$. Different body size, bone to muscle to fat ratio and/or gastrointestinal contents volume as well as subjectivity of body condition scoring can be considered as a possible explanation of the mentioned variability of detected relationships as Frutos et al. (1997) previously published.

The modelling of relationships among BCS and particular indicators of developing body tissues were also engaged in previous studies of milk and multiple purpose sheep. Caldeira and Portugal (2007) showed an increase of total (up to 1.185\%) as well as subcutaneous (up to $1.622 \%$ ) fat with a BCS increase from 1 to 4 points. According to their study there was also a variability of $192 \%$ in the increase of the muscle content together with a particular BCS from 1 to 4 . There is a similar increase of all indicators in accordance with our study. The higher variability of results presented by Caldeira and Portugal (2007) can be explained by different data obtaining when the total muscle and fat tissue content weighing $(\mathrm{kg})$ was performed in sheep carcasses. Sanson et al. (1993) noted that one BCS point was equal to a $1.10 \mathrm{~mm}$ increase of BT. Their results show a similar tendency as ours but the increase in Suffolk sheep in our study is on average 1.66 mm higher compared to Sanson et al. (1993). According to the results it is obvious that the ewes' BCS expressed rather their fat reserves than the muscle development. The fat tissue is a primary energy source and muscle tissue secondary, as documented by the proportion corresponding to particular BCS points. This is in agreement with Bellová et al. (2009) who noted that an organism uses fat reserves primarily during physiological stress (e.g., the postpartum period) due to their higher energetic value $(2$ to $3 \times)$ compared to muscle tissue. Similarly Sanson et al. (1993) found positive regression between LW and BT, when in their study a $1 \mathrm{~kg}$ increase of LW corresponded to $0.2 \mathrm{~mm}$ deeper BT. They did not concern the relation to MLLT depth but MLLT area, which showed positive linear regression with LW $\left(+0.21 \mathrm{~cm}^{2}\right.$ per $\left.1 \mathrm{~kg}\right)$. The positive tendency in both body tissues development was observed in our study as well. Similarly to the previous statement, the higher LW reflected higher food intake and subsequently was manifested by higher tissue development of MLLT and BT especially (Ptáček et al. 2013).

Caldeira and Portugal (2007) claimed that BCS estimation is influenced by the muscle and fat development. However, these authors were not concurrently concerned with the relationship and mutual proportions of these tissues. But their statement was confirmed by linear regression between BT and MLLT in our study. It can be concluded that BCS as a trait of the nutritional status and body development is formed not only by fat reserves, but by muscle depth as well.

This study provides a complex overview of the ewe body tissue development and their proportions, and connects them with other indicators of the ewes' nutritional status documented by BCS and LW. Results of presented study could serve in flock management as a tool for evaluation of the current nutritional status as well as a basic ground for further research focused on development of sheep fattiness and carcass traits evaluation. 


\section{Acknowledgment}

The study was supported by the "S" grant of MŠMT ČR, 21320/1312/3179, and NAZV QH81324. We thank Mrs. Lois Russell for editorial help with this manuscript.

\section{References}

Bellová V, Pechová A, Dvořák R, Pavlata L 2009: Influence of full-fat soybean seeds and hydrolyzed palm oil on the metabolism of lactating dairy cows. Acta Vet Brno 78: 431-440

Body condition scoring of sheep. Oregon State University Extension Service Web site. Available at: http://ir.library.oregonstate.edu/xmlui/handle/1957/14303?show=full. Last modified February 10, 2010. Accessed February 10, 2010.

Caldeira RM, Portugal AV 2007: Relationships of body composition and fat partition with body condition score in Serra da Estrala ewes. Asian Australas J Anim Sci 20: 1108-1114

Frutos P, Mantecón AR, Giráldez FJ 1997: Relationship of body condition score and live weight with body composition in mature Churra ewes. Anim Sci 64: 447-452

Kenyon PR, Morel PCH, Morris ST 2004: Effect of live weight and condition score of ewes at mating and shearing mid-pregnancy on birth weights and growth rates of twin lambs to weaning. NZJ Agric Res 52: 145-149

Kenward MG, Roger JH 1997: Small sample inference for fixed effects from restricted maximum likelihood. Biometrics 53: $983-997$

Milerski M 2007: The methodology of meatiness and fattiness ultrasound measurement in lambs and kids (in Czech). Institute of Animal Science, Prague, $12 \mathrm{p}$.

Młynek K, Janiuk I, Dzido A 2012: Effect of growth intensity of bulls on the microstructure of musculus longissimus lumborum and meat quality. Acta Vet Brno 81: 127-131

Ptáček M, Ducháček J, Stádník L, Beran J, Štolc L 2014: Effects of ewes’ live and backfat thickness at mating of fertility and production performance in Suffolk sheep and their crosses. Bulg J Agric Sci (in press)

Ptáček M, Štolc L, Stádník L, Kluková H 2013: In vivo assessment of growth traits and meat production in Charollais and Kent lambs. Sci Agric Bohem 44: 10-17

Russel AJ, Doney FJM, Gunn RG 1969: Subjective assessment of fat in live sheep. J Agric Sci 72: 451-454

Sanson DW, West TR, Tatman WR, Riley ML, Judkins MB, Moss GE 1993: Relationship of body composition of mature ewes with condition score and body weight. J Anim Sci 71: 1112-1116

SAS Institute Inc. 2011. SAS/STAT ${ }^{\circledR} 9.3$ User's Guide. Cary, NC: SAS Institute Inc.

Sezenler T, Özder M, Yildirir M, Ceyhan A, Yüksel MA 2011: The relationship between body weight and body condition score some indigenous sheep breeds in Turkey. J Anim Plant Sci 21: 443-447

Stádník L, Ježková A, Louda F, Dvořáková J, Štolc L 2009: The relationships among lumbar region width, back muscling and musculus longissimus lumborum et thoracis area in Blonded'Aquitaine bulls and heifers during rearing period. Arch Tierz 52: 243-254

Vatankhah M, Talebi MA, Zamani F 2012: Relationship between ewe body condition score (BCS) at mating and reproductive and productive traits in Lori-Bakhtiari sheep. Small Ruminant Res 106: 105-109

Żarczyńska K, Sobiech P, Pomianowski A, Waclawska-Matyjasik A, Stopyra A, Illek J 2012: Changes of selected biochemical indicators and electrocardiography indicators in nutritional muscular dystrophy in calves. Acta Vet Brno 81: 119-125 